\title{
Kasus limfoma pada anjing golden retriever
}

\author{
Ayu Syilvita Amanda* \\ Rumah Sakit Hewan Jawa Barat, Lembang, Bandung Barat, Jawa Barat, INDONESIA
}

\begin{abstract}
ABSTRAK: Limfoma adalah kanker pada sistem limfatik. kasus limfoma belum diketahui penyebabnya, namun terdapat beberapa faktor resiko yang dapat memicu terjadinya limfoma. Limfoma sering terjadi pada anjing berusia diatas 1 tahun atau berkisar pada usia 10 tahun. Tulisan ini melaporkan kasus limfoma pada anjing Golden Retriever betina berusia 8 tahun. Diagnosa dilakukan melalui pemeriksaan fisik dan kimia darah, sedangkan pemeriksaan penunjang berupa sitologi dan histopatologi tidak dilakukan dalam kasus ini. Terapi yang digunakan yaitu bedah pengangkatan kanker, lalu pemberian antibiotik dan antiinflamasi untuk pascabedah. Luka bekas jahitan menutup selama kurang lebih 6 minggu. Pemberian antibiotik topikal dan salep ekstrak placenta sangat membantu mempercepat pertumbuhan jaringan kulit.
\end{abstract}

Kata kunci:

limfoma, anjing, Golden Retriever.

\section{- PENDAHULUAN}

Limfoma adalah kanker yang terjadi pada sistem limfatik. Sistem limfatik terdiri dari pembuluh limfatik, kelenjar getah bening dan organ limfatik. Sistem limfatik memiliki sirkulasi yang terhubung satu sama lain. Oleh karena itu, jika terjadi kelainan atau tumor maka akan dapat menyebar melalui sirkulasi tersebut. Limfoma terdiri dari Limfoma Hodgkin dan Non-Hodgkin (Mengko \& Surarso 2009). Limfoma Hodgkin adalah limfoma yang terjadi akibat mutasi sel limfosit B, sedangkan limfoma non-Hodgkin terjadi karena mutasi DNA pada sel B dan T. Limfoma Non-Hodgkin sering terjadi pada anjing yaitu sekitar $83 \%$ dari kasus lymphohematopoietic. Kasus pada anjing usia $<1$ tahun yaitu 1,5/ 100.000 kasus, sedangkan anjing usia 10 tahun yaitu 84/100.000 kasus (Marconato et al. 2013).

Penyebab limfoma belum sepenuhnya diketahui, namun ada beberapa faktor resiko yang dapat memicu terjadinya limfoma. Faktor resiko ini mencakup usia, perubahan genetik, infeksi, radiasi bahan kimia, dan penyakit imunodefiensi tertentu (Mengko \& Surarso 2009). Diagnosa limfoma harus melalui beberapa tes agar dapat mengetahui stadium kanker yang dialami pasien. Stadium kanker limfoma dibagi menjadi 4 yaitu stadium I, II, II, dan IV. Stadium I yaitu sel kanker berkumpul menjadi kelompok di daerah tertentu kelenjar getah bening. Stadium II yaitu sel limfoma berada pada sekurang-kurangnya 2 kelompok di kelenjar getah bening. Stadium III limfoma terdapat pada kelompok kelenjar getah bening di atas maupun di bawah diafragma, atau di organ atau jaringan sekitar getah bening. Stadium IV limfoma sudah menyebar ke seluruh satu organ atau jaringan selain kelenjar getah bening, atau bisa juga berada dalam organ hati, darah, atau sumsum tulang (Kemenkes RI 2015).

\section{- KASUS}

Anamnesa dan sinyalemen: Seekor anjing Golden Retriever betina berusia 8 tahun datang ke Rumah Sakit Hewan Jawa Barat. Pemilik menyatakan bahwa benjolan yang ada di dekat kaki depan berawal dari ukuran kecil, lalu terus membesar dalam 1 tahun terakhir. Pemeriksaan fisik: Anjing memiliki berat badan $46 \mathrm{~kg}$. Suhu tubuh 40,6 ${ }^{\circ}$. Kondisi umum fisik tidak ada kelainan. Namun ada benjolan besar di area belakang kaki kiri depan berbentuk bulat dengan diameter kurang lebih $25 \mathrm{~cm}$. Dipermukaan benjolan tersebut terdapat sedikit erosi kulit. Saat dipalpasi benjolan terasa kenyal dibagian pinggir dan agak keras dibagian tengah (Gambar 1). Diagnosa: Limfoma. Terapi dan Penanganan: Penanganan yang dilakukan adalah bedah pengangkatan limfoma. Tindakan pascabedah adalah pemberian antibiotik, antiinflamasi dan salep ekstrak plasenta pada bekas jahitan. Prognosa: Dubius, perlu pemeriksaan lebih lanjut mengenai jenis limfoma.

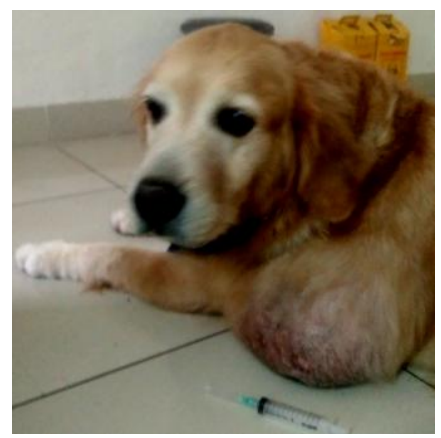

Gambar 1 Limfoma pada anjing Golden Retriever.

Diterima: 07-04-2019 | Direvisi: 28-04-2019 | Disetujui: 01-05-2019

(C) 2019 CC-BY-SA. Ini adalah artikel Open Access yang didistribusikan berdasarkan ketentuan dari Creative Commons Attribution ShareAlike 4.0 International License (https://creativecommons.org/licenses/by-sa/4.0/). 


\section{- HASIL DAN PEMBAHASAN}

Pemeriksaan kimia darah menjadi bahan mempertimbangan sebelum tindakan bedah pengangkatan tumor dilakukan. Penunjang diagnosa sitologi dan histopatologi sebaiknya dilakukan untuk penegakan diagnosa yang lebih baik. Akan tetapi pada kasus ini, pemeriksaan penunjang tersebut tidak dilakukan. Hasil pemeriksaan darah menunjukkan fungsi hati masih normal, namun fungsi ginjal agak menurun karena beberapa parameter memiliki nilai lebih rendah dari normal yaitu BUN $5 \mathrm{mg} / \mathrm{dl}$, CA $4 \mathrm{mg} / \mathrm{dl}$, PHOS 2,2 mg/dl. Pembiusan total kemudian dilakukan menggunakan sediaan Ketamine dan Xylazine dan dikombinasi dengan anestesi Inhalasi sebelum tindakan bedah. Pembedahan untuk mengangkat jaringan dilakukan dengan membuat sayatan di bagian tengah benjolan pada bagian luka yang terbentuk akibat bersentuhan antara benjolan dengan lantai (Gambar 2A). Jaringan kemudian dipreparir sampai semua bagian tumor terlepas dari jaringan normal. Preparir dilakukan secara hati-hati karena banyak pembuluh darah yang aktif (Gambar 2B). Setelah semua jaringan sudah dipastikan terangkat, penutupan dilakukan dengan menjahit kulit (Gambar 2C).

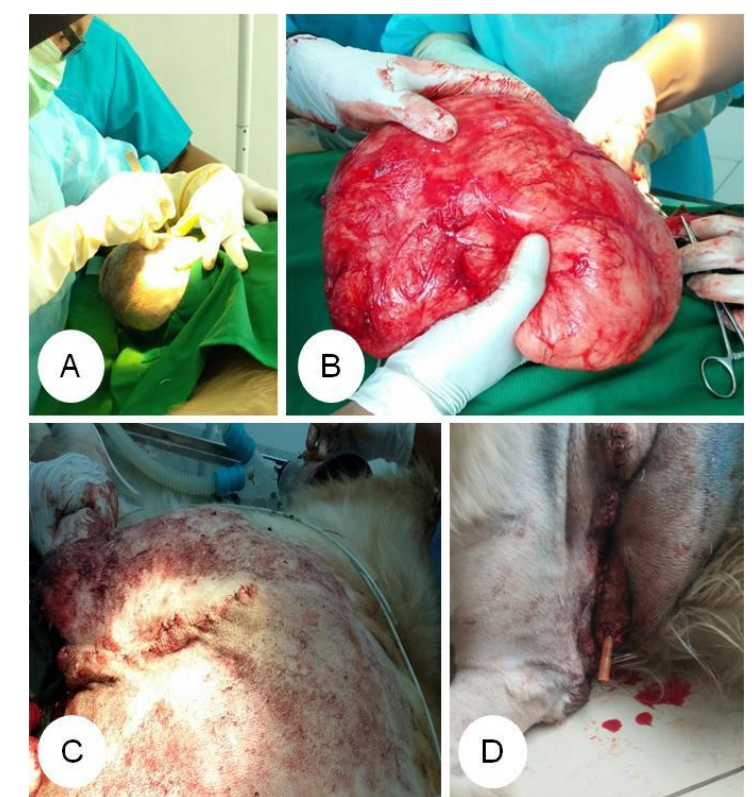

Gambar 2 Prosedur bedah. (A) sayatan pada titik orientasi, (B) jaringan tumor yang telah terangkat, $(C)$ penjahitan jaringan dan kulit, dan (D) pemasangan pipa saluran irigasi jaringan.

Tindakan perawatan jaringan pascabedah dilakukan sebagaimana rekomendasi Liptak (1997) yaitu pemberian antibiotik, antiinflamasi, dan penambah darah selama 7 hari. Pemberian antiobiotik jenis tetracycline dan enrofloxacin dapat digunakan selain amoxicillin. Vitamin K1 dapat diberikan untuk menghentikan perdarahan dalam jaringan (Fry et al. 2003). Elizabeth Collar dipasangkan pada leher agar anjing tidak menjilat luka jahitan.

Jahitan terbuka pada hari ke-8 dan penjahitan ulang dilakukan sekaligus dipasang pipa (selang) irigasi cairan dari jaringan (Gambar 2D). Selang irigasi dibuat untuk mempermudah proses flushing dan agar cairan dari bawah kulit dapat keluar dari jaringan secara langsung sehingga benang jahit pada jahitan relatif tidak basah. Daerah jahitan kemudian diberikan salep antibiotik secukupnya yang mengandung Gentamicin dan Neomisin+ekstrak plasenta (Bioplacenton ${ }^{\circledR}$ ). Antibiotik metronidazole dan cefixime juga diberikan. Selang irigasi lepas dan jahitan masih terbuka sedikit di bagian tengah setelah hari ke-15. Flushing tetap dilanjutkan tanpa harus memasang selang dan salep terus diberikan. Anjing dibawa pulang oleh pemilik pada hari ke-17 dan sebelumnya diberikan edukasi tentang tatacara perawatan luka yang masih terbuka. Informasi dari pemilik setelah 2 minggu kemudian (hari ke-30) didapatkan bahwa luka jahitan sudah menutup dengan baik. Secara umum penyembuhan pada anjing lebih cepat dibandingkan pada kucing. Luka pada anjing menutup berlangsung dari pertumbuhan jaringan bagian dalam dan dilanjutkan proses epitelisasi sel kulit, sedangkan pada kucing luka menutup dari tepi menuju ke pusat luka (Bohling et al. 2004).

\section{- SIMPULAN}

Limfoma merupakan kanker yang sering terjadi pada anjing. Tindakan bedah dapat dilakukan untuk mengangkat jaringan. Perawatan pascabedah harus dilakukan secara intensif dan persembuhan luka bedah dapat berlangsung dalam beberapa minggu.

\section{— INFORMASI PENULIS}

Penulis untuk Korespondensi

*ASA: ayusylvita@gmail.com

Medik Veteriner, Rumah Sakit Hewan Jawa Barat

Jl. Tangkuban Perahu KM. 22, Desa Cikole, Kec. Lembang,

Kab. Bandung Barat, Prop. Jawa Barat, INDONESIA

\section{- PUSTAKA ACUAN}

Bohling MW, Henderson RA, Swaim SF, Kincaid SA, Wright JC. 2004. Cutaneous Wound Healing in the Cat: A macroscopic Description and Comparison with Cutaneous Wound Healing in the Dog. Veterinary Surgery. 33(6): 579587.

Fry MM, Vernau W, Pesavento PA, Brömel C, Moore PF. 2003. Hepatosplenic lymphoma in a dog. Veterinary pathology. 40(5):556-62.

[Kemenkes RI]. 2015. Infodatin Pusat data dan Informasi Kementerian Kesehatan RI. Kementerian Kesehatan Republik Indonesia. ISSN 2442-7659.

Liptak JM. 1997. An overview of the topical management of wounds. Australian veterinary journal. 75(6):408-13.

Marconato L, Gelain ME, Comazzi S. 2013. The dog as a possible animal model for human non-Hodgkin lymphoma: a review. Hematological oncology. 31(1):1-9.

Mengko SK, Surarso B. 2009. Patogenesis Limfoma Non Hodgkin Ekstra Nodal Kepala dan Leher. Jurnal THT-KL. 2(1):32-47. 